\title{
PEDAGOGICAL CONDITIONS TO FORM THE PROFESSIONAL COMPETENCE OF THE FUTURE ROAD TRANSPORT MANAGERS
}

The Ukraine's accession to the implementation of the Bologna Declaration principles i.e. creation of a general labor market of the highest qualification in Europe ensuring the qualitative educational level of specialists and compliance of their preparation with the conditions of the international labor market, enhances the relevance of the professional competence formation issues for a specialist. At the same time, training of specialists of the necessary personal and professional qualities is impossible without transformation of the existing subject-to-knowledge education and transition to the competence approach in training, which is considered to be the important approach of renewal the education content.

Road transport determines the efficiency of the development of productive forces and directly influences both the formation of the labor market and all aspects of human's social activity. Thus, the proper specialists' preparation in the field of road transport organization is important.

The analysis of teaching a number of special disciplines for students of specialty 275 "Transport technologies", the survey of road transport experts and students allowed identifying the basic pedagogical conditions to create the future transportation manager professional competence: determination and selection of educational content in accordance with the present-day socio-economic and employers' requirements; modeling of the future professional activity of graduates; formation of professional attitude in respect to the future workplace activities; creation of pedagogically comfortable educational environment.

The realization of these conditions should be ensured by the introduction of separate content modules in psychological and pedagogical and professional disciplines, the use of methods of active learning; analysis of specific situations, business games, discussions, more active involvement of students into research work-participation in student scientific conferences, writing of papers and projects, joint decision of creative tasks. In evaluating the results of the learning process organization, a priority should be given to dialogic interaction, objective review of completed tasks.

Thus, the creation of the above-stated pedagogical conditions should help to ensure a high level of professional competence of the future transportation managers.

Key words: training, professional competence, pedagogical conditions, transportation manager.

\section{(статтю подано мовою оригіналу)}

The social and economic transformations taking place in Ukraine testify to the need for society in specialists who are able to effectively resolve issues arising during their professional activities. The main goal of professional higher education is the training of skilled workers that are fluent in professional knowledge, are ready for continuous professional growth, independence and self-realization. Today, there is a certain contradiction that has arisen between the future specialist' requirements and the capabilities of the present educational system.

Road transport is one of the developed branches of social production, which affects all aspects of human activity and society as a whole, determines the effectiveness of the development of production forces, and satisfies the economic and social needs of enterprises and the population.

However, despite the importance of the proper functioning of this sector of the economy, some contradictions between the following remain unresolved: existing educational technologies versus current labor market requirements; high requirements for the transportation managers versus the lack of technologies for competence assessment; the absence of scientifically substantiated pedagogical conditions for transportation manager professional competence versus the need for the conditions to be implemented during the training activity.

In this regard, the issue to generate the professional competence of these specialist capable of ensuring the road transport stable functioning as an important industry of the country's economy is of the particular importance.

The main purpose of the article is to determine the pedagogical conditions to create the professional competence of the future transportation managers.

Analysis of recent research and publications. Abroad, the considerable attention is paid to the study of the concept of "pedagogical conditions" and the determination of their content. In [1, p. 6] the concept of "condition" is interpreted as the environment in which certain actions take place. Paper [2, p. 11] believes the pedagogical conditions are a pedagogical comfortable environment. In the study [3, p. 23] it is a set of educational process measures to ensure the students to achieve the appropriate level of training.

Ukrainian authors also study pedagogical conditions in order to increase the educational process effectiveness. The authors [4, p. 132] understand the pedagogical conditions as the factors affecting the process of achieving the goal dividing them into external and internal ones. External factors are the relations between the teacher and the student, the place of study, the climate in the team, etc. At the same time, the internal factors are the individual properties of students, for instance, their state of health, character peculiarities, existing abilities and skills. In [5, p. 156] the pedagogical conditions are a functional dependence of the essential components of a pedagogical phenomenon on a complex of objects (things, their states, processes, interactions) in different manifestations. The study [6, p. 183] considers the pedagogical conditions as a system, the main components of which are certain norms, methods, material conditions, real situations to achieve a pedagogical goal. 
Thus, taking into account the previous opinions of researchers, we believe the pedagogical conditions as the set of activities to create an educational process using present technologies to provide the formation of a person of the needed level of professional competence, which allows performing his professional duties in a timely and qualitative manner. When defining the pedagogical conditions, we took into account the requirements of the current social and economic environment, the peculiarities of the professional competence formation and the prospects for the education system development.

Main material presentation. To determine the measures for the of professional competence formation of the future graduates in the field of road transport, 23 officials in motor transport enterprises of Kharkiv and Kharkiv region and 320 students studying in specialty 275 "Transport Technologies" were covered. The survey showed that the most significant components of improving the effectiveness of the educational process in relation to the professional competence can be taken to the following: individual training approach, practical training and the ability of team working. The results of the study became the grounds for determining the pedagogical conditions to create the professional competence of students of the above-mentioned specialty.

Thus, the pedagogical conditions necessary for the formation of professional competence of transportation managers, namely: 1) determination and selection of the educational content in accordance with current social and economic and employers' requirements; 2) modeling of the future professional activities of graduates; 3) formation of a professional attitude in relation to the future activities at the place of work; 4) creation of a pedagogically comfortable educational environment.

The first pedagogical condition is necessary for the adjustment of curricula and programs in accordance with the requirements of the labor market in the field of management and organization of road transport and related industries in order to increase a specialist professional readiness for the future professional activities. On the one hand, it involves constant monitoring of the labor market by the graduating department in order to take into account the special components of the transportation manager that are currently necessary for road transport (logistician, passenger or freight transportation process engineer, freight forwarder and others), lecturing (or optional courses) directly from the heads of enterprises, a questionnaire among the motor transport and freight forwarding enterprises regarding their needs for graduates and the professional qualities of graduates.

On the other hand, the criteria for selecting the educational content should be both qualification characteristics (skills, knowledge and personal qualities of future specialists) as well as curricula and educational programs to represent the content of educational information and a set of educational tasks to ensure the formation of a system of knowledge and skills, and contribute to the development of professional competence components.

The second pedagogical condition allows eliminating the contradictions between the theoretical training of students in higher education and their future practical activities. An analysis of the quality of specialists' preparedness 'indicates that university graduates are not always able to transfer the theoretical knowledge to the practical activities. Modeling of future professional activity involves, firstly, ensuring its completeness, that is, practical preparation for performing all basic professional functions, and secondly, its integrity - the readiness to perform not only individual operations or functions, but also whole activities at a particular workplace. Thus, this pedagogical condition provides a relatively "painless" transition to the actual implementation of their professional functions.

Modeling of professional activity in the educational process acts as a specific learning technology. Its essence lies in the fact that students reproduce professional activities in the learning process in specially created conditions, when this activity is conditionally professional in nature, and when performing actions or operations, only its most significant features are manifested. The need to recreate professional activity is also determined by a number of reasons directly related to student learning. Firstly, such reproduction gives students an idea of the whole content of professional activity, internal structure, interconnection and interdependence of its elements. Secondly, the development of the model makes it possible to combine information on individual aspects of professional activity dispersed over different courses, and thereby creates the opportunities for systematization and identification of missing material.

During the training, the third pedagogical condition should promote to the formation of a professional attitude to future activities through the development of students' key competencies (components of professional competence), which provide the ability of a future specialist to be competitive in the labor market and further sustainable labor activity in a current market economy. Key competencies are the individual abilities necessary for successful activity in specific production situations. They are not personal characteristics of a specialist in any industry, but are formed in the learning process and directly during the course of labor activity. The integration of theoretical, practical knowledge and experience of professional activity leads to the creation and further development of key competencies to solve a number of problematic issues generating the universality of the specialist.

In our opinion, the main conditions for the formation of a professional attitude to future activities are: organizational conditions (curriculum, lesson schedule, material and technical equipment of the educational process); educational and methodological conditions (selection of the task content, integration of various courses); technological conditions (organization of active forms of training, use of innovative training technologies); psychological and pedagogical conditions (diagnostics of students' development, learning stimulation system, professional competence criteria determination).

The fourth pedagogical condition is aimed at creating the comfortable conditions from the point of view of pedagogical conditions, i.e. a comfortable environment for the implementation of the educational process in the most 
general sense and the organizational and technical support of the educational process, which will contribute to better assimilation of educational material. If we consider the concept of "comfort" from the point of view of pedagogical conditions, then, first of all, we understand it as a set of conditions for the development and formation of professional competence of the future specialist. The main components of a pedagogically comfortable environment, we also consider the psychological climate, unity of the group, promotion of self-realization of students.

Psychological climate are the interpersonal relationships to be typical for a group of students that determine its ability to learn. The more these relationships are "unified" with respect to the proper perception or are aimed at the perception of the educational process, understanding the importance of mastering the knowledge, the higher the learning ability will be. Close issue to the concept of the psychological climate is the unity of the group, which is understood as a union of persons in which both the conditions for the development of objective activity and the development of individual qualities are created. It generates the assimilation of knowledge within a certain activity.

Conclusions. Thus, we believe that the creation of the above conditions will help to ensure a high level of professional competence of students in the field of transportation management organization in road transport, and thus contribute to the employment of graduates, positive feedback from employers, and the formation of a steady interest of students in mastering the specialty.

\section{Bibliography:}

1. Salganik L., Rychen D. Projects on Competencies in the Educational Context. Neuchâtel : Foundation Of Theoretical and Conceptual Analysis, 1999. 12 p.

2. Spector Michael J. Competencies and Standards for Instructional Design and Educational Technology. Discussion Paper. Montreal : University of Quebec at Montreal, 2006. 21 p.

3. Spencer L., Spencer S. Competence at work: models for superior performance. New York : John Wiley \& Sons, Inc. 1993.55 p.

4. Організація самостійної роботи студентів в умовах інтенсифікації навчання / А. М. Алексюк та ін. Київ : ІСДО, 1993. 336 с.

5. Чижевський Б. Г. Організаційно-педагогічні умови становлення ліцеїв в Україні. Київ : Інститут педагогіки АПН України, 1996. 249 c.

6. Підготовка майбутнього вчителя до впровадження педагогічних технологій / О. М. Пєхота та ін. Київ : А.С.К. 2003.240 с.

\section{References:}

1. Salganik L., Rychen D. Projects on Competencies in the Educational Context. Neuchâtel : Foundation Of Theoretical and Conceptual Analysis, 1999. $12 \mathrm{p}$.

2. Spector Michael J. Competencies and Standards for Instructional Design and Educational Technology. Discussion Paper. Montreal : University of Quebec at Montreal, 2006. 21 p.

3. Spencer L., Spencer S. Competence at work: models for superior performance. New York : John Wiley \& Sons, Inc. 1993.55 p.

4. Orhanizatsiya samostiynoyi roboty studentiv $v$ umovakh intensyfikatsiyi navchannya (1993) [Organization of students' independent work in the conditions of learning intensification] / A. M. Alexyuk et al. Kyiv : ISDO. 336 s. [in Ukrainian]

5. Chyzhevs'kyy B. H. (1996) Orhanizatsiyno-pedahohichni umovy stanovlennya litseyiv v Ukrayini [Organizational and pedagogical conditions of formation of lyceums in Ukraine]. Kyiv : Institute of Pedagogics of the Academy of Pedagogical Sciences of Ukraine. 249 s. [in Ukrainian]

6. Pidhotovka maybutn'oho vchytelya do vprovadzhennya pedahohichnykh tekhnolohiy (2003) [Preparing a future teacher for the implementation of pedagogical technologies] / O. M. Pyekhota et al. Kyiv: A.S.K. 240 s.

Копитков Д. М., Копиткова Т. Г. Педагогічні умови формування професійної компетентності фахівців з організації перевезень на автомобільному транспорті

Приєднання України до реалізації принципів Болонської декларації, тобто утворення єдиного ринку праці вищої кваліфікації в Свропі, забезпечення якісного освітнього рівня фахівців і відповідності їх підготовки умовам міжнародного ринку праці, посилює актуальність питання формування професійної компетентності сучасного фахівия. Водночас підготовка фахівиів із необхідними особистісними й професійними якостями є неможливою без трансформаиї існуючої предметно-знаннєвої освіти й переходу до компетентнісного підходу в навчанні, щэо розглядається як одне з важливих положень оновлення змісту освіти.

Автомобільний транспорт визначає ефективність розвитку виробничих сил і безпосередньо впливає на як формування ринку праці, так і на всі аспекти діяльності людини та суспільства. Отже, відповідна підготовка фахівців у галузі організації його роботи набуває особливого значення.

Аналіз діяльності з викладання низки фахових дисииллін для студентів спеціальності 275 "Транспортні технології", опитування фахівиів галузі автомобільного транспорту та студенів, дали змогу виокремити основні, педагогічні умови, необхідні для формування професійної компетентності майбутніх інженерів з організачії перевезень і управління на автомобільному транспорті, а саме: визначення й відбір змісту освіти відповідно до сучасних соціально-економічних вимог та вимог роботодавців; моделювання майбутньої професійної діяльності випускників; формування професійного ставлення до майбутньої діяльності на місиі роботи; створення педагогічно комфортного освітнього середовища.

Реалізація таких умов має забезпечуватися через уведення окремих змістовних модулів у психолого-педагогічні та фахові дисципліни, використання методів активного навчання, аналізу конкретних ситуацій, ділових ігор, дискусій, більш активного залучення студентів до науково-дослідної роботи: участь у студентських наукових конференціях, написання курсових робіт та проєктів, спільне розв'язання творчих завдань. Під час оцінки результатів такої організації навчального процесу перевага має віддаватися діалогової взаємодії, об'єктивній взаємоперевіриі та рещензуванні виконаних завдань.

Таким чином, створення вищезазначених педагогічних умов має сприяти забезпеченню високого рівня професійної компетентності майбутніх фахівців у галузі організації перевезень і управління на автомобільному транспорті.

Ключові слова: навчання, професійна компетентність, педагогічні умови, фахівець з організації перевезень. 


\section{FORMATION OF THE COMMUNICATIVE COMPONENT OF PROFESSIONAL IDENTITY OF FUTURE SPECIALISTS IN PHYSICAL THERAPY, ERGOTHERAPY}

The purpose of the article is to investigate the formation of the communicative component of professional identity of future specialists in physical therapy, ergotherapy. The communicative component of professional identity contributes to the development of the professional image of "I" of the future specialist through the formation of a community of cognitive and practical activities, relationships and communication in the professional team, socialization of the individual - through the development of skills to establish and maintain effective communication with other people. The communicative component implies the presence of a set of professional and personal qualities, skills, skills, which are the basis of a specialist's readiness for pedagogical communication with representatives of various social and age groups, direct him to search and make effective decisions in situations of interaction with students, parents, colleagues. to listen, understand and be understood by other subjects of communication. For the purpose of scientific substantiation and experimental verification of the complex of psychological and pedagogical conditions that contribute to the development of the communicative component of professional identity in the future specialists in physical therapy, ergotherapy, the authors organized a study in which 310 students participated in 1-2 courses of the Department of Physical Therapy. It is established that the values of development of the communicative component of professional identity of future specialists in physical therapy are predominantly specialized; the ability to describe their own and others' feelings and experiences by reducing the level of alexithymia; in developing communication skills. This is especially important at the stage of formation and development of socio-professional activity, since the future professional activity of physical therapists and ergotherapists is connected with communication, and the orientation towards acceptance of a partner for communication is a necessary motivational trend in the profession.

Key worlds: professional identity, future specialists, communicative component, education, vocational training, vocational education pedagogy, physical therapy, ergotherapy.

\section{(статтю подано мовою орихіналу)}

At the present stage of development of society, an important task of education is the development of students' communicative tolerance in the sociocultural environment. This is of great importance for their professional and personal development. The relevance of the study is due to the need of society for specialists in physical therapy and ergotherapy - responsible, with self-esteem, tolerantly interacting with people from different social groups, different ages, different ethnic backgrounds.

One of the fundamental tasks of the professional training of future specialists in physical therapy, ergotherapy is to form in the future physical therapists and ergotherapists a view of their future professional activity as a single interdependent whole, the ability to see and understand the problems that arise and ways.

Future physical therapists or ergotherapists should be carriers of human and cultural values and strive for selfimprovement. Their professional competence is formed in the process of teaching not only special, but also general education disciplines. Researchers believe that the integration of general education with the professional provides motivation for their study, resulting in the formation of professional identity.

Professional identity is associated with the processes of professional self-determination, personalization and selforganization, awareness of oneself as a representative of a particular profession and professional community, characterized by a degree of identification-differentiation of oneself with business and others, manifested in cognitive-emotional-behavioral self.

Professional identity in its concept is closely interrelated with concepts such as professional development, professionalism, professional self-esteem, professional self-determination, and is one of the main criteria for becoming a professional in a competitive environment. In other words, in order to exist in dynamic socio-economic conditions, a modern professional must be capable of continuous development and analysis, an awareness of his place in the professional environment. The formation of a professional identity is the most important task that a professional faces in the period of his / her professional development.

Theoretical analysis of different concepts and approaches to the study of this concept allows us to define the concept of "identity" as a multidimensional and integrative psychological phenomenon, which is the result of an active process of self-representation associated with the continuous process of development of human personality throughout his life. At the same time, it should be noted that this process is not a linear process and can have the opposite effect, returning to a lower level. In doing so, a person makes a series of interrelated choices, taking on their personal goals, values, beliefs.

A person's professional choice is a lengthy process that involves a series of interrelated decisions and stages, spanning over ten years. The process of choosing a profession is irreversible, which ends in a compromise between external and internal factors. By external factors we mean the prestige of the profession, the situation in the labor market, internal - individual psychological characteristics of the individual [4].

The purpose of the article is to investigate the formation of the communicative component of professional identity of future specialists in physical therapy, ergotherapy. 
The communicative component of professional identity contributes to the development of the professional image "I" of the future specialist through the formation of a community of cognitive and practical activities, relationships and communication in the professional team, socialization of the individual - through the development of skills and ability to establish and maintain effective communication with other people $[1,2,6]$. The communicative component implies the presence of a set of professional and personal qualities, skills, skills, which are the basis of a specialist's readiness for pedagogical communication with representatives of various social and age groups, direct him to search and make effective decisions in situations of interaction with students, parents, colleagues. to listen, understand and be understood by other subjects of communication.

The communication activity of a specialist in physical rehabilitation is a constant component of his professional activity, since the specifics of his work as a teacher implies that he is both a source of information and the organizer of the rehabilitation process, relationships and communication in the team. There is no doubt that the level of professional identity of a future physical rehabilitation specialist depends on the level of development of his or her communication skills.

When considering the communicative component as a capacity for therapeutic effects, its content can be cited as an opportunity to establish effective relationships between the rehabilitation specialist and the patient according to his condition and diagnosis. In general, none of the functions of a specialist in physical rehabilitation can be realized beyond the limits of his interaction and communication with patients, that is, in the professional activity of communication is a universal category $[3,6,10]$.

We consider it appropriate to single out the following components in the structure of the communicative component of the professional identity of the cognitive: cognitive (awareness and internalization of the ideas of tolerant communication); instrumental (mastery of a set of communicative skills); conative (initiative, activity and social responsibility, dialogue dialogue); emotional (the attitude of the individual to the process and the results of tolerant communication, satisfaction with the system of interpersonal relationships) [1, 7, 8]. This structure of communicative tolerance reflects the unity of the substantive and procedural aspects of the development of future specialists in physical therapy, ergotherapy of communicative tolerance in the social and cultural environment of a higher educational institution [3,9].

Future specialists in physical therapy and ergotherapy, in our opinion, are in the system of social relations, which is aimed at the formation of social and professional activity during the period of education. The development of communicative tolerance can be carried out both within the framework of teaching the disciplines of the humanitarian cycle in the formation of communicative skills, and in educational educational extracurricular activities.

For the purpose of scientific substantiation and experimental verification of the complex of psychological and pedagogical conditions that contribute to the development of communicative tolerance among future specialists in physical therapy, ergotherapy, the authors in 2015 - 2019. A study was organized in which 310 students of 1-2 courses of the Department of Physical Therapy took part.

The main research methods were: observation, diagnostic, linear experiment, conversation, questioning; popular diagnostic techniques - V.V. Boiko diagnosis of the level of empathic abilities; Ladanov, V.A. Urazaev diagnosis of motivational orientations in interpersonal communications; T. Lyry methodology "Study of communicative characterological trends"; V.V. Boiko diagnosis of communicative tolerance; N.P. Fetyskyn, V.V. Kozlov, H.M. Manuilov Diagnostics of communicative social competence.

As a result of the study, it was revealed that the average (54\%) and underestimated level of empathy development prevails among students (33\%). And only $4 \%$ of students are characterized by a high level of development of empathy and $9 \%$ - a low level. In general, students are focused on understanding a communication partner (43\% of students have a high level of orientation on understanding a partner, $37 \%$ of students have an average level of this orientation). In the process of interpersonal interaction, subjects try to accept a communication partner as he is $(31 \%$ are characterized by showing respect for the personality of the communication partner, accepting his personality and interests). A compromise orientation has an average level of severity in $68 \%$ of students. Subjects tend to exercise restraint in conflict situations, to take into account the point of view of the interlocutor and his interests. $53 \%$ of students have an average level of expression of the general harmony of motivational tendencies in interpersonal relationships. 56\% of students are characterized by an average level of development of communicative tolerance.

In general, the orientation toward the adoption of a communication partner is a necessary motivational tendency in the profession of a physical therapist. In his activity, a physical therapist and occupational therapist should strive to consider him as a person and individuality and accept him as he is, with its advantages and disadvantages.

Experimental experimental work on the development of communicative tolerance of future specialists in physical therapy, ergotherapy is aimed at implementing the system of psychological and pedagogical conditions that we have identified and includes:

- enrichment of students' knowledge on this issue at lectures, seminars, extracurricular independent work in the following disciplines: philosophy, pedagogy, professional mastership, psychology, using various technologies: interactive forms of work, group work, business game, trainings, interactive communication at the lecture, problematic discussions;

- development of students' communicative tolerance in cognitive activity through participation in various events: festivals, conferences, round tables, lectures, curatorial hours; the assimilation of moral standards and standards 
of behavior through the inclusion of students in joint social activities (volunteer activities, participation in student social organizations).

Taking into account the content of communicative tolerance in the context of ideas of personality-oriented education, the main means of creating pedagogical situations aimed at developing communicative tolerance of future specialists in physical therapy, ergotherapy, are dialogue - as a way of mastering personal experience, business and role-playing game - as a means of modeling the socio-cultural environment. The developed typology of the "dialogue" was applied and games and trainings were designed: role-playing, associative, communicative, active, the joint use of which created the conditions for more effective achievement of the goals at each stage. The work on the development of communicative tolerance involves two areas: the first is the mastery of the theoretical and practical side of communicative tolerance under the guidance of a teacher; the second is the independent activity of students in extracurricular activities.

At the control stage of the experiment, the effectiveness of the practice-oriented work was assessed by the level criterion of the dynamics of the development of communicative tolerance. The study of the characteristics of the emotional sphere of students confirmed our assumption that they need to develop communicative tolerance, since many of them have a fairly high level of alexithymia, which is manifested in the difficulty in verbalizing emotional states. However, during the experiment, positive dynamics and a tendency to move to a higher level of development of communicative tolerance and empathic communication were revealed. Indicators of a high level of empathy increased from 4 to $9 \%$, average - from 54 to $57 \%$, and underestimated decreased from 33 to $29 \%$ and low - from 9 to 5\%; the propensity for communicative tolerance increased from 56 to $61 \%$.

So, the results of an experimental study confirm the feasibility of choosing a set of psychological and pedagogical conditions that ensure the development of communicative tolerance among future specialists in physical therapy and ergotherapy in a higher educational institution.

Factors contributing to the development of communicative tolerance include:

- the formation of the spiritual culture of student society: the students' joint experience of a sense of belonging to the student subculture, belonging to an educational institution, familiarization with high life goals and values;

- the functional inclusion of teachers in joint activities with students, in accordance with the organizational order, rules and traditions adopted at the university;

- the saturation of the educational process with group and individual actions of various kinds: events, sports, contests, art.

Therefore, the main importance of the development of the communicative component of the professional identity of future specialists in physical therapy, egrotherapy is to increase the level of empathy; the ability to describe their own and other people's feelings and experiences through a decrease in the level of alexithymia; in the development of communication skills. This is especially important at the stage of formation and development of social and professional activity, since the future professional activities of physical therapists and occupational therapists are associated with communication, and orientation toward the adoption of a communication partner is a necessary motivational tendency in the profession.

Bibliography:

1. Балданова Е. А. Развитие коммуникативной толерантности студентов технического вуза средствами иностранного языка : дис. ... канд. пед. наук. Улан-Удэ, 2011. 219 с.

2. Гребенец Е. С. Формирование коммуникативной толерантности у старшеклассников во внеучебной деятельности : дис. ... канд. пед. наук. Москва, 2013. 173 с.

3. Громкова М. Т. Психология и педагогика профессиональной деятельности : учебное пособие для вузов. Москва : Юнити-Дана, 2003. 415 с.

4. Дмітрієва Н. С., Копочинська Ю. В. Формування професійної ідентичності майбутніх фахівців із фізичної терапії як фактор підвищення їх конкурентоспроможності. Збірник наукових праиь Херсонського державного університету. Педагогічні науки. 2019. Вип. 79(3). С. 105-110. DOI : 10.32999/ksu2413-1865/2019-87-19.

5. Каган М. С. Мир общения: проблемы межсубъектных отношений. Москва : Политиздат, 1998. 315 с.

6. Калач Е. А. Учебно-профессиональное взаимодействие как фактор успешного развития коммуникативной толерантности студентов специальности «связи с общественностью» : дис. ... канд. пед. наук. Ижевск, 2006. 223 с.

7. Климов Е. А. Индивидуальный стиль деятельности в зависимости от типологических свойств нервной системы. Казань, 1969. $237 \mathrm{c}$.

8. Скрябина А. Б. Педагогические условия формирования коммуникативной толерантности у старшеклассников : дис. ... канд. пед. наук. Кострома, 2000. 209 с.

9. Толстикова С. Н. Развитие коммуникативной толерантности у будущих социальных педагогов системы образования : дис. ... канд. психол. наук. Калуга, 2002. 176 с.

10. Яцевич Л. П. Формирование коммуникативной толерантности у будущих специалистов социальной работы : дис. ... канд. пед. наук. Чита, 2010. 193 с.

\section{References:}

1. Baldanova E. A. (2011). Razvytye kommunykatyvnoi tolerantnosty studentov tekhnycheskoho vuza sredstvamy ynostrannoho yazyka : dys. kand. ped. nauk [The development of communicative tolerance of students of a technical university by means of a foreign language: dis. Cand. ped Sciences]. Ulan-Ude, p. 219. 
2. Hrebenets, E. S. (2013). Formyrovanye kommunykatyvnoi tolerantnosty u starsheklassnykov vo vneuchebnoi deiatelnosty : dys. kand. ped. nauk [Formation of communicative tolerance in high school students in extracurricular activities: dis. Cand. ped Sciences]. Moscow, p. 173.

3. Hromkova M. T. (2003). Psykholohyia y pedahohyka professyonalnoi deiatelnosty : Uchebnoe posobye dlia vuzov [Psychology and pedagogy of professional activity: Textbook for universities]. Moscow: Yunyty-Dana.

4. Dmitriieva N. S., Kopochynska Yu. V. (2019). Formuvannia profesiinoi identychnosti maibutnikh fakhivtsiv z fizychnoi terapii yak faktor pidvyshchennia yikh konkurentospromozhnosti [Formation of the Professional Identity of Future Physical Therapy Specialists as a Factor for Increasing their Competitiveness]. Zbirnyk naukovykh prats [Khersonskoho derzhavnoho universytetu]. Pedahohichni nauky [Collection of Scientific Papers [Kherson State University]. Pedagogical Sciences], 79(3), p. 105-110. DOI : 10.32999/ksu2413-1865/2019-87-19.

5. Kahan M. S. (1998) Myr obshchenyia: problemy mezhsubektnykh otnoshenyi. The world of communication: problems of intersubjective relations. Moscow: Polytyzdat, 1998. 315 p.

6. Kalach E. A. (2006). Uchebno-professyonalnoe vzaymodeistvye kak faktor uspeshnoho razvytyia kommunykatyvnoi tolerantnosty studentov spetsyalnosty «sviazy s obshchestvennostiu» : dys. kand. ped. nauk [Educational-professional interaction as a factor in the successful development of communicative tolerance of students of the specialty "public relations": dis. Cand. ped sciences]. Izhevsk, p. 223.

7. Klymov E. A. (1969). Yndyvydualnyi styl deiatelnosty v zavysymosty ot typolohycheskykh svoistv nervnoi systemy [Individual style of activity depending on the typological properties of the nervous system]. Kazan.

8. Skriabyna A. B. (2000). Pedahohycheskye uslovyia formyrovanyia kommunykatyvnoi tolerantnosty u starsheklassnykov : dys kand. ped. nauk [ Pedagogical conditions for the formation of communicative tolerance in high school students: dis. Cand. ped Sciences]. Kostroma, p. 209.

9. Tolstykova S. N. (2002). Razvytye kommunykatyvnoi tolerantnosty u budushchykh sotsyalnykh pedahohov systemy obrazovanyia : dys. kand. psykhol.nauk [The development of communicative tolerance in future social educators of the educational system: dis. Cand. Psychol.Science]. Kaluha, p. 76.

10. Yatsevych L. P. (2010). Formyrovanye kommunykatyvnoi tolerantnosty u budushchykh spetsyalystov sotsyalnoi raboty : dys. kand. ped. nauk [Formation of communicative tolerance among future specialists in social work: dis. Cand. ped sciences]. Chyta, p. 193.

Копочинська Ю. В. Формування комунікативного компонента професійної ідентичності майбутніх фахівців із фізичної терапії, ерготерапії

Метою статті є дослідження формування комунікативного компонента професійної ідентичності майбутніх фахівців із фізичної терапї, ерготерапї. Комунікативний компонент професійної ідентичності сприяє розвитку професійного образу «Я» майбутнього фахівия через формування спільності пізнавально-практичної діяльності, взаємовідносин та спілкування у професійному колективі, соиіалізації особистості за рахунок розвитку вмінь $і$ навичок установлення й підтримання ефективного спілкування з іншими людьми. Комунікативний компонент передбачає наявність сукупності професійно-особистісних якостей, умінь, навичок, які є основою готовності фахівия до педагогічного спілкування з представниками різноманітних соціальних та вікових груп, спрямовують його на пошук та прийняття ефективних рішень у ситуаиіях взаємодії з учнями, батьками, колегами, розвивають уміння слухати, розуміти й бути зрозумілим для інших суб' єктів комунікації. 3 метою наукового обтрунтування та експериментальної перевірки комплексу психологічних і педагогічних умов, щзо сприяють розвитку комунікативного компонента професійноі ідентичності у майбутніх фахівців із фізичної терапії, ерготерапії, авторами проведено дослідження, в якому взяло участь 310 студентів I-II курсів кафедри фізичної терапії. Установлено, щцо переважно розвиток комунікативного компонента професійної ідентичності майбутніх фахівців із фізичної терапії, егротерапіі полягає у підвищенні рівня емпатії; здатності описати власні $і$ чужі почуття $і$ переживання через зниження рівня алекситимї̈; у розвитку комунікативних навичок. Це особливо важливо на етапі становлення і розвитку соціально-професійної активності, оскільки майбутня професійна діяльність фізичних терапевтів і ерготерапевтів пов'язана зі спілкуванням і орієнтація на прийняття партнера по спілкуванню є необхідною мотиваційною тенденцією у професії.

Ключові слова: професійна ідентичність, майбутні фахівиі, комунікативний компонент, освіта, професійна підготовка, педагогіка професійної освіти, фізична терапія, ерготерапія. 